\title{
Many Moving Parts: The Latest Look Inside the U.S. Labor Market
}

\author{
$\underline{\text { David Andolfatto and Marcela M. Williams }}$
}

\begin{abstract}
The U.S. economy has gained roughly 2.8 million jobs since early 2010. That may be cold comfort, considering that more than 8 million jobs have been lost since the recession began. The Federal Reserve has lowered its policy rate as far as it can go, and the economy is flush with liquidity. Yet the unemployment rate remains persistently high. From policymakers to private citizens, the debate continues over what to do to help the labor market adjust. Disagreements stem, in part, from the complicated nature of the labor market itself. There are many moving parts, and the authors examine several here, pointing out that a "one size fits all" approach may not accommodate the differences across various sectors of the economy. The authors examine structural change, "frictions" in matching workers with job openings, lack of consumer and business confidence, the severity of the past recession, and other factors to help inform and illuminate this complex policy debate. (JEL J20, J60, J64)
\end{abstract}

Federal Reserve Bank of St. Louis Review, March/April 2012, 94(2), pp. 135-51.

The U.S. economy lost more than 8 million jobs in the latest recession and the three subsequent quarters, while the unemployment rate rose to nearly 10 percent. Roughly 2.8 million jobs have been added to the economy since early 2010, but the unemployment rate remains persistently high. Some policymakers are concerned about the prospect of a prolonged "jobless recovery," a period of rising average income (gross domestic product, GDP) with little or no employment growth. There is considerable debate over what, if anything, monetary and fiscal policy can or should do to help the labor market adjust in the wake of one of the worst recessions since the Great Depression.

Disagreements over what should be done to stimulate the labor market stem, in part, from its complicated nature. The labor market has many moving parts, and policies frequently have unintended consequences. The purpose of this essay is to describe a few of these moving parts and to explain why it is sometimes difficult to interpret the ups and downs we experience in the labor market. One theme that emerges is that the big picture, as seen in the aggregated data, is

David Andolfatto is a vice president and economist and Marcela M. Williams is a Public Affairs officer at the Federal Reserve Bank of St. Louis. This article is an updated version, using the most recent data, of the 2010 Federal Reserve Bank of St. Louis Annual Report, "Many Moving Parts: A Look Inside the U.S. Labor Market"; www.stlouisfed.org/publications/ar/2010/pages/ar10_1.cfm. The authors thank Kristie Engemann and Constanza Liborio for valuable research assistance.

( ) 2012, The Federal Reserve Bank of St. Louis. The views expressed in this article are those of the author(s) and do not necessarily reflect the views of the Federal Reserve System, the Board of Governors, or the regional Federal Reserve Banks. Articles may be reprinted, reproduced, published, distributed, displayed, and transmitted in their entirety if copyright notice, author name(s), and full citation are included. Abstracts, synopses, and other derivative works may be made only with prior written permission of the Federal Reserve Bank of St. Louis. 


\section{Andolfatto and Williams}

not always representative of what is happening up close, as seen in the data that have been dissected.

We begin by looking at the timeline of U.S. employment since World War II. Employment, measured as a ratio of population size, remains relatively stable over time. This overall behavior, however, masks several underlying trends. For example, employment rates have generally been rising for women and falling for men. We look next at the share of employment across different sectors of the economy. Again, we see sharp differences in the evolution of employment over even relatively short periods of time. These different behaviors suggest, among other things, a degree of caution in the use of a "one size fits all" policy affecting the labor market.

We will then turn to the issue of unemployment. Contrary to common belief, unemployment is not technically a measure of joblessness. It is, instead, a measure of job search activity among the jobless. Millions of unemployed people find jobs every month, even in a deep recession. Millions of workers either lose or leave their jobs every month, too, even in a robust expansion. The large and simultaneous flow of workers into and out of employment suggests that the labor market plays an important role in reallocating human resources to their most productive uses through good times and bad.

The job search activity of unemployed workers is mirrored on the other side of the labor market with the recruiting efforts of firms that have unfilled job openings. It is a property of the labor market that job vacancies coexist with unemployed workers, a fact that suggests the presence of "frictions" in the process of matching workers to jobs.

Vacancy and unemployment rates tend to move in opposite directions over the business cycle. Normally, good times induce firms to create job openings, and those additional openings then make it easier for unemployed workers to find jobs. However, the usual relationship between unemployment and vacancies sometimes breaks down. Since the end of the latest recession, for example, job openings in the United States appear to have increased-yet unemployment remains persistently high. Some economists interpret this as evidence that the latest recession has led to "structural" change, which will take some time to work through.

Indeed, history shows that the unemployment rate frequently does take a long time to decline following a recession. Given the severity of the most recent recession and given recent experience, it is likely to take years before the unemployment rate falls back to its pre-recession levels.

\section{EMPLOYMENT}

Everyone has a common-sense notion of what it means to be employed. But to measure employment, the concept has to be defined precisely. Doing this is not as straightforward as one might imagine.

We are all given a gift of time: 24 hours a day, 7 days a week, 52 weeks a year, and so on. We generally have many competing uses for our time. Deciding how to spend a fixed amount of time across competing uses is a problem familiar to most of us. Some time is devoted to the office, some to the gym, some to household chores, and so on. The time "employed" in many of these different activities could rightfully be described as "work." A stay-at-home parent may legitimately be said to have a "job" (and an important one, at that). Going down this path, however, soon leads to the conclusion that almost everyone could be classified as "employed" in the 
sense of engaging in some productive activity. There may very well be some merit to this point of view.

In everyday language, however, a "job" or "employment" is commonly associated with an activity that generates a monetary reward. This is essentially the way statistical agencies measure employment. Standard labor force surveys record a person as employed in a given month if he or she reports having performed any paid work in the previous four weeks. The term "paid" should be understood here as direct monetary compensation by another party (an employer or, in the case of the self-employed, a customer).

Understanding how employment is defined and measured is important for how its level is interpreted. An increase in employment is usually thought to be a good thing and, indeed, it frequently is. But employment may also increase when, for example, a student cannot afford to remain in school or when a stay-at-home parent is forced to find a paying job. Clearly, it is not in the interest of society to have everyone employed. But if this is the case, then how is "full employment" to be defined and measured?

The idea that the economy is at full employment when everyone who wants a job has a job is not very helpful. Almost anybody can get some sort of job in relatively short order. The problem for most people is in finding a high-paying job that they enjoy doing. Everybody wants this type of job even if he or she is currently engaged in other productive activities, such as going to school or minding the household. Conceptual difficulties such as these have led some economists to look to the data for guidance. In particular, might it be possible to identify full employment by appealing to some long-run historical average level of employment?

Figure 1 plots the evolution of employment in the United States from 1948 to the present. Because employment will grow naturally along with the population, it is sometimes more illuminating to examine the behavior of employment relative to population size. The employment population ratio recorded in Figure 1 represents employment divided by the relevant population. 1

In the postwar era, the U.S. employment rate has averaged about 60 percent and has remained, for the most part, within 4 percentage points of this average over the sample period. Because the population base is large, a small change in the employment rate can translate into millions of jobs. For example, during the most recent recession, the employment rate declined by more than 3 percentage points, which corresponds to a decline of almost 8 million jobs. Today, the employment rate seems to have leveled off at roughly 4 percentage points below its level at the peak of the past recession.

Figure 1 also reveals an interesting difference in how male and female employment rates have evolved over time. First, while employment rates are lower for females relative to males, this gap has closed significantly over the past 60 years. Male employment rates show a persistent decline in the first half of the sample, while female employment rates are generally on the rise. While these long-run adjustments appear to have stabilized over the past 20 years or so, it remains unclear whether some notion of "full employment" can be identified in these data. If it can, then it would appear to differ across the sexes and fluctuate over time.

Employment rates in different sectors of the economy are also evolving. Figure 2 shows the employment-population ratios for eight sectors; these ratios have been normalized at 100 in the first quarter of 2000. The subsequent points on each curve can then be interpreted as the percentage change in that sector's employment population ratio since the beginning of 2000. If an 


\section{Andolfatto and Williams}

\section{Figure 1}

\section{U.S. Employment-to-Population Ratio, 1948:Q1-2011:Q4}

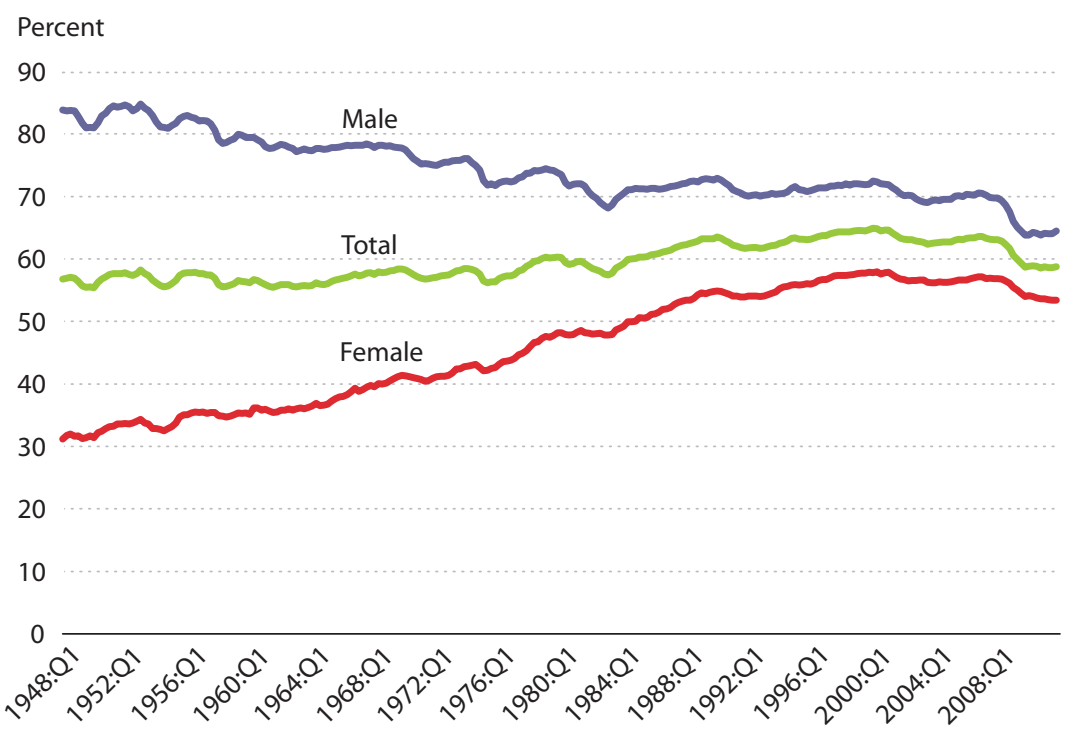

SOURCE: Bureau of Labor Statistics/Haver Analytics.

\section{Figure 2}

Evolution of Sectoral Employment, 2000:Q1-2011:Q3

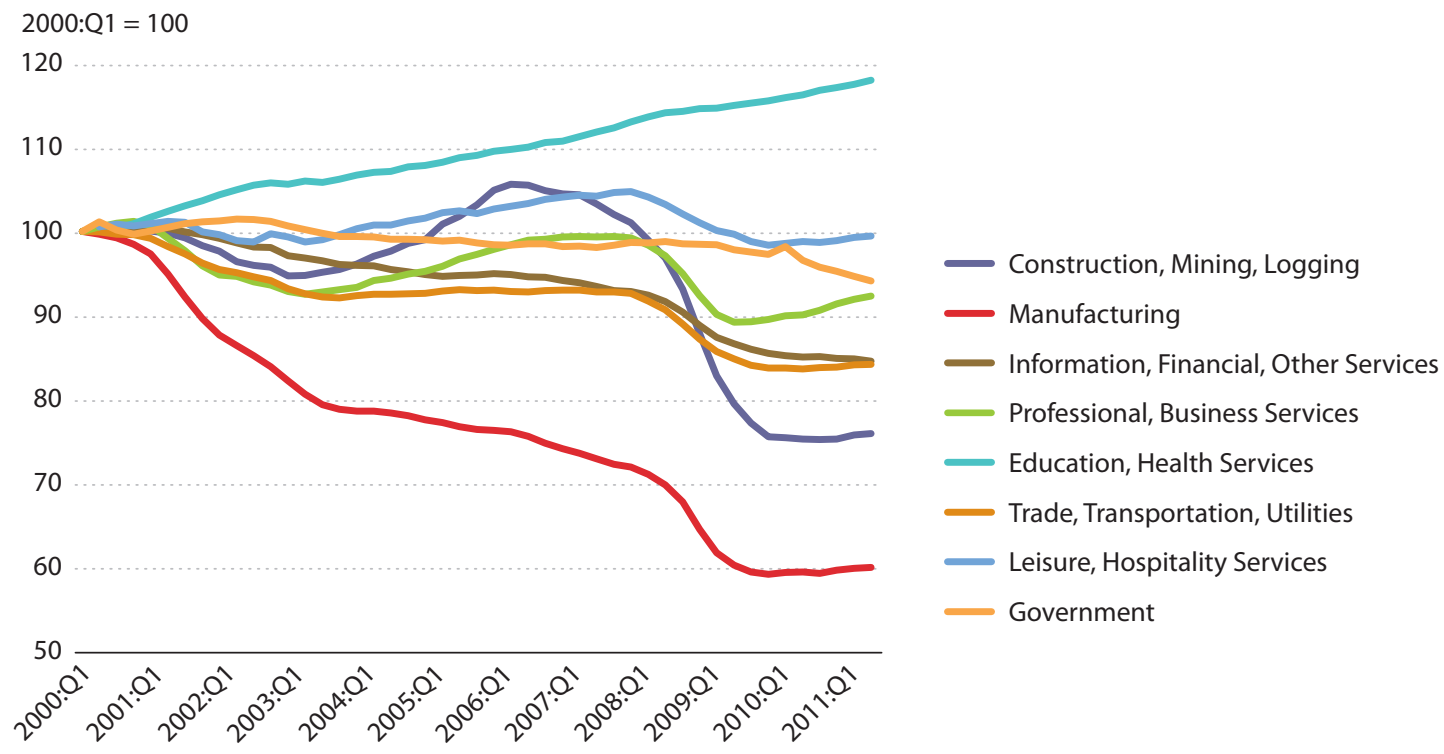

SOURCE: Bureau of Labor Statistics/Haver Analytics. 
economy were to grow along what economists call a "balanced growth path," then all of the lines in Figure 2 could be expected to fluctuate around the normalized value of 100. But there appear to be clear trends in at least two sectors: Manufacturing sector employment is in longrun decline, while employment in the education and health services sector is steadily on the rise-even through the most recent recession. In terms of cyclicality, there is no surprise. To take two extremes, construction sector employment is highly cyclical, while government sector employment is not. Roughly half of the industries in Figure 2 display employment levels that have leveled off during the past year, while most other industries experienced an increase.

\section{Unemployment}

According to Figure 1, about 40 percent of the U.S. adult population is "jobless" at any point in time. Joblessness (nonemployment), however, is not the same thing as unemployment, at least according to standard labor force survey definitions. To be classified as unemployed, a nonemployed person must report being available for paid work and having engaged in some job search activity in the previous four weeks. $\stackrel{2}{-}$ Nonemployed persons who are not actively looking for jobs are classified as nonparticipants.

Conceptually, the distinction between unemployment and nonparticipation is clear enough; it involves some notion of active job search. The standard labor force survey asks nonemployed people what they have done to find work (in the previous four weeks). If the respondents answer "nothing," then they are classified as nonparticipants. Almost any evidence of active job seeking

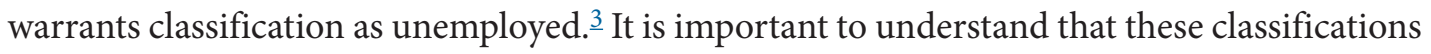
are determined by the surveyor. The people being surveyed are never asked directly whether they are unemployed or not.

From an economic perspective, then, a nonemployed person who had one job interview in four weeks may not look that much different from a nonparticipant. Indeed, our clean conceptual distinctions are clouded further by the fact that, in any given month, the number of nonparticipants who find jobs is as large as the number of unemployed who do.

On the other hand, the data show that an unemployed person is more likely to find a job than a nonparticipant. This difference in the probability of finding a job suggests that the unemployed are in some sense "more attached" to the labor market than nonparticipants are. It is for this reason that the labor force is defined as the sum of employment and unemployment. The implication is that nonparticipants are "not in the labor force."

When a recession hits, the unemployment rate typically spikes very quickly and sharply. Over the course of the subsequent recovery, however, the unemployment rate typically declines much more gradually. Figure 3 shows this pattern quite clearly for the United States. It evidently takes a lot of time to rebuild the job-worker relationships that are destroyed in a severe recession. If history is any guide, then one should not expect the U.S. unemployment rate to fall back to pre-recession levels for many years to come. It is also important to note that even though the unemployment rate remains high, it has declined from its peak of 9.9 percent in the fourth quarter of 2009.

One should keep in mind that unemployment rates, like most measures of labor market activity, often vary significantly across economic and demographic characteristics, such as income, age, sex, and education. 


\section{Andolfatto and Williams}

Figure 3

U.S. Unemployment Rate, 1976:Q1-2011:Q4

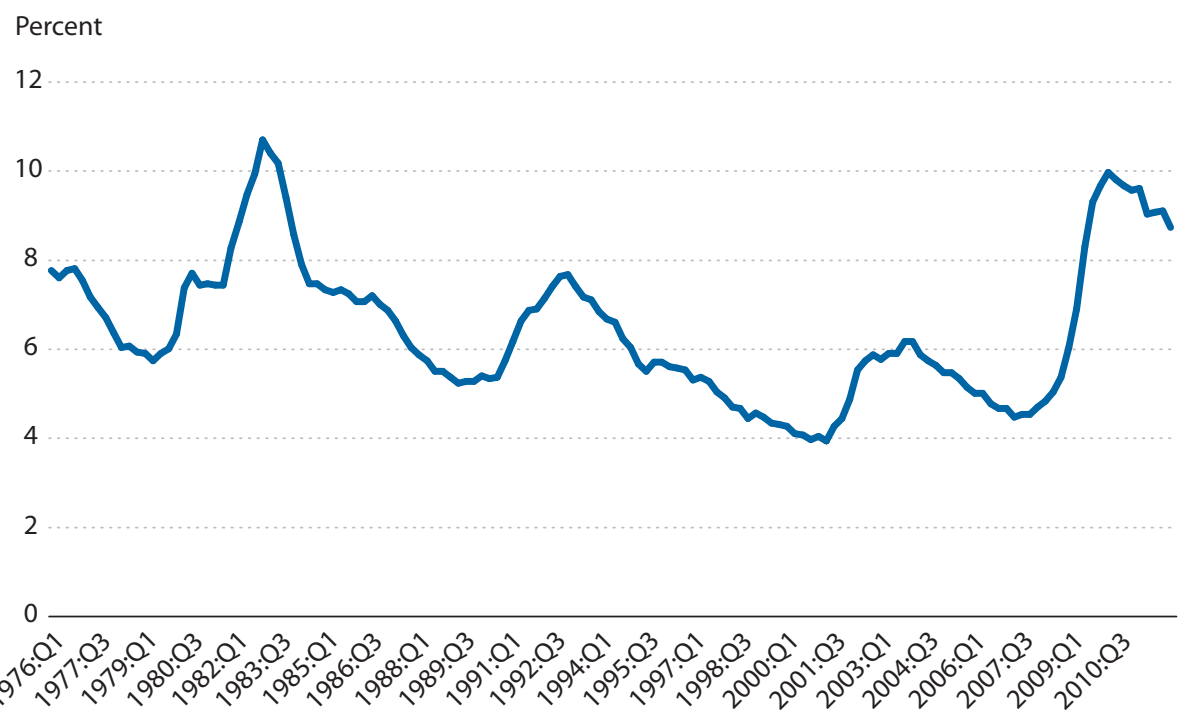

SOURCE: Bureau of Labor Statistics/Haver Analytics.

Figure 4

U.S. Unemployment Rates across Education Groups (Ages 25+), 2000:Q1-2011:Q4

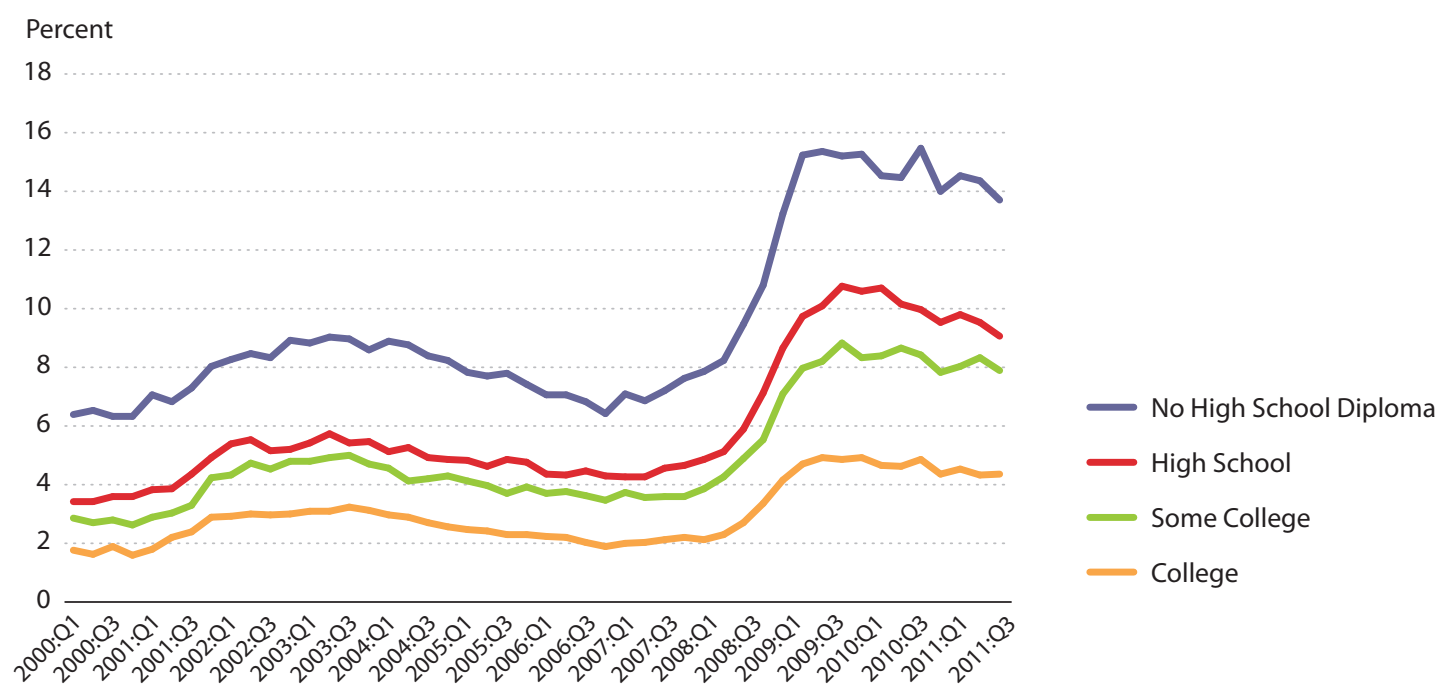

SOURCE: Bureau of Labor Statistics/Haver Analytics. 
Figure 4 depicts the unemployment rates for four educational attainment categories in the United States since the year 2000. As one might expect, the incidence of unemployment falls more heavily on the less educated. A high school dropout, for example, is roughly three times more likely to be unemployed than a college graduate. It is interesting to note, however, that the unemployment rates across all education categories increased at roughly the same proportion during the past recession. Since the end of this most recent recession, however, the unemployment rate has decreased for all education groups. This decline has been more pronounced for high school dropouts and high school graduates and appears to have leveled off for college graduates.

\section{LABOR MARKET TRANSITIONS}

The categories of employment, unemployment, and nonparticipation represent snapshots of labor market activity at a point in time. But workers belonging to a given category will not necessarily remain in that category for long. Over a given interval of time, a number of workers will make transitions from one labor market category to another. These transitions are called "worker flows."

An analogy may be of some use here: Imagine a bathtub of water, with its drain unstopped, and the faucet turned on. The level of water at a point in time corresponds to the level of employment. The water draining from the tub corresponds to the flow of workers losing or leaving their jobs. The water pouring in from the faucet corresponds to the flow of workers finding jobs. Whether the water level rises or falls depends on the relative size of the inflow and outflow. And so it is with the level of employment, unemployment, and nonparticipation.

It is of some interest to measure worker flows because their magnitude reveals something about the fluidity of the labor market. Do labor market categories such as unemployment, for example, represent stagnant pools of workers who exhibit little mobility? Or is there a flurry of economic activity hidden below the surface? As it turns out, data from the Current Population Survey (CPS) can be used to answer this question.

Figure 5 examines CPS data over the 2002-11 period. The left panel of Figure 5 examines CPS data over the period before the latest recession (January 2002 to November 2007) and divides the adult U.S. population into three familiar categories. The average monthly level of employment was 133 million workers, while the average monthly level of unemployment was 8 million workers. The average number of adults out of the labor force was 76 million.

The numbers associated with the arrows in Figure 5 represent average worker flows per month. These monthly flows are huge in relation to population size. For example, 11.6 million workers moved into and out of employment every month on average from January 2002 to November 2007. That's 140 million transitions into and out of employment over the course of a year, a number that is larger than the average number of people employed at any given time.

Several other interesting facts are evident from Figure 5. Although about 5.8 million workers left employment every month, fewer than half of these workers became unemployed-rather, most left the labor force. Similarly, about 3.8 million workers left unemployment. But only 2 million of these workers found jobs; the rest left the labor force. 
Figure 5

\section{Average Worker Flows, January 2002-December 2011}
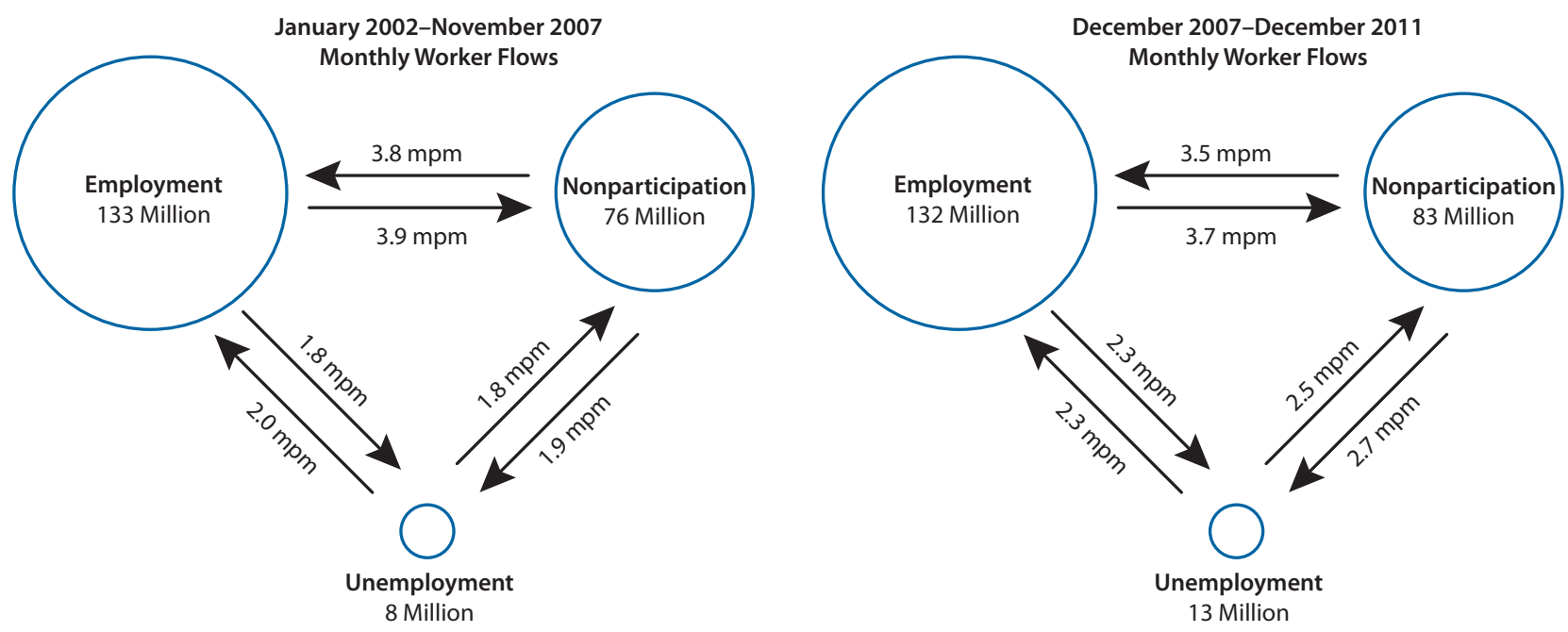

NOTE: $\mathrm{mpm}=$ millions per month .

SOURCE: Current Population Survey, Bureau of Labor Statistics/Haver Analytics.

The right panel of Figure 5 examines CPS data over the period since the latest recession began (December 2007 to December 2011). During this period, the average level of employment has been lower than pre-recession levels by 1 million workers, while the average level of unemployment increased significantly to 13 million workers. The average number of adults out of the labor force also increased to 83 million.

Labor flows into and out of employment also rose since the start of the latest recession. Specifically, 11.9 million workers moved into and out of employment every month, which implies 142 million transitions over the course of a year. While 6 million workers left employment every month, about 4.9 million workers left unemployment every month.

Economists Steven Davis, R. Jason Faberman, and John Haltiwanger suggested in a 2006 paper that the economic forces behind these worker flows can be grouped into "supply" side and "demand" side. On the demand side, employers continuously create new jobs and destroy old ones, a process that evidently accounts for much of the observed job mobility and many of the jobless spells experienced by workers. On the supply side, workers frequently switch jobs and change their labor market status for any number of reasons, including retirement, family relocation, schooling, and so on. Also on the supply side, new workers are entering the labor force.

As one might expect, there is considerable cyclical (as well as seasonal) variation in these flows. Figure 6 plots the average monthly flow of workers for the United States from 2006:Q1 to 2011:Q4. The shaded region represents the most recent recession.

The top-left panel plots the flow of workers into and out of employment (nonemployment is the sum of unemployment and nonparticipation). Not surprisingly, there is a sharp spike in the flow of workers leaving employment during the recession. There is also a moderate decline 


\section{Figure 6}

\section{U.S. Labor Market Flows, 2006:Q1-2011:Q4}
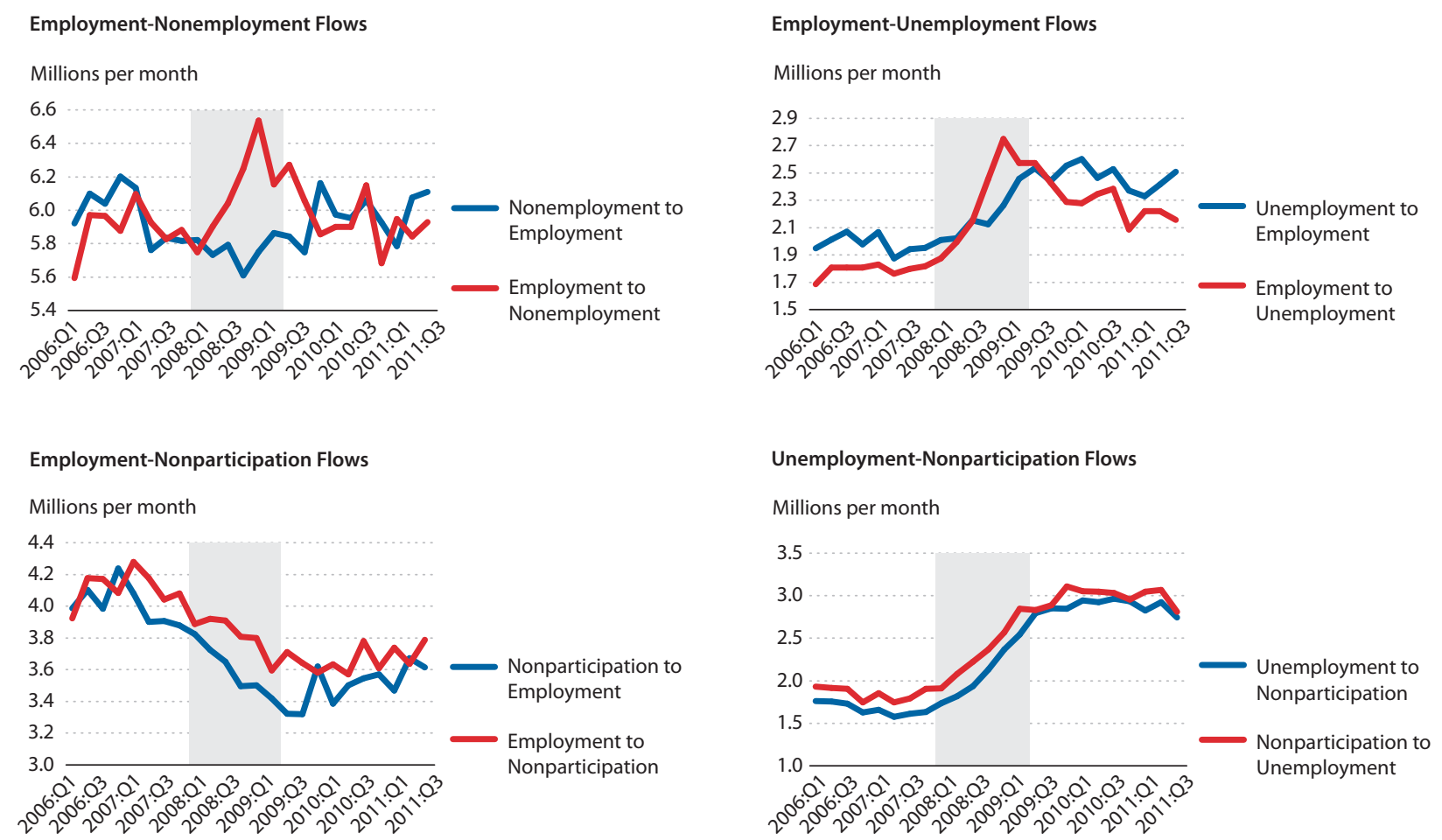

NOTE: Shaded areas represent recessions as determined by the National Bureau of Economic Research.

SOURCE: Current Population Survey, Bureau of Labor Statistics/Haver Analytics.

in the flow of workers into employment. It is interesting to note that an average of 5.6 million workers per month found jobs even in the depths of the recession. The flow of workers losing or leaving their jobs, however, was much higher. The difference in these two flows accounts for the sharp recent decline in employment recorded in Figure 1.

The top-right panel shows a large increase in the flow of workers moving from employment to unemployment during the recession. This is what one would expect when the economy sours. But there is also a significant, though less pronounced, increase in the number of unemployed workers finding jobs. This latter increase is due, in part, to the fact that there are now more unemployed workers. But as unemployed workers have the option of leaving the labor force, the fact that more unemployed workers are finding jobs must to some extent also reflect a growing availability of job opportunities.

The bottom-left panel depicts the flows of workers between employment and nonparticipation. Both of these flows declined throughout the recent recession. It is evidently not as easy to find a job while out of the labor force. And likewise, workers appear less inclined to leave the labor force as the economy worsens.

The bottom-right panel depicts the flows of workers between unemployment and nonparticipation. The unemployment to nonparticipation flow rose throughout the recession; this might 


\section{Figure 7}

\section{Unemployment Duration}
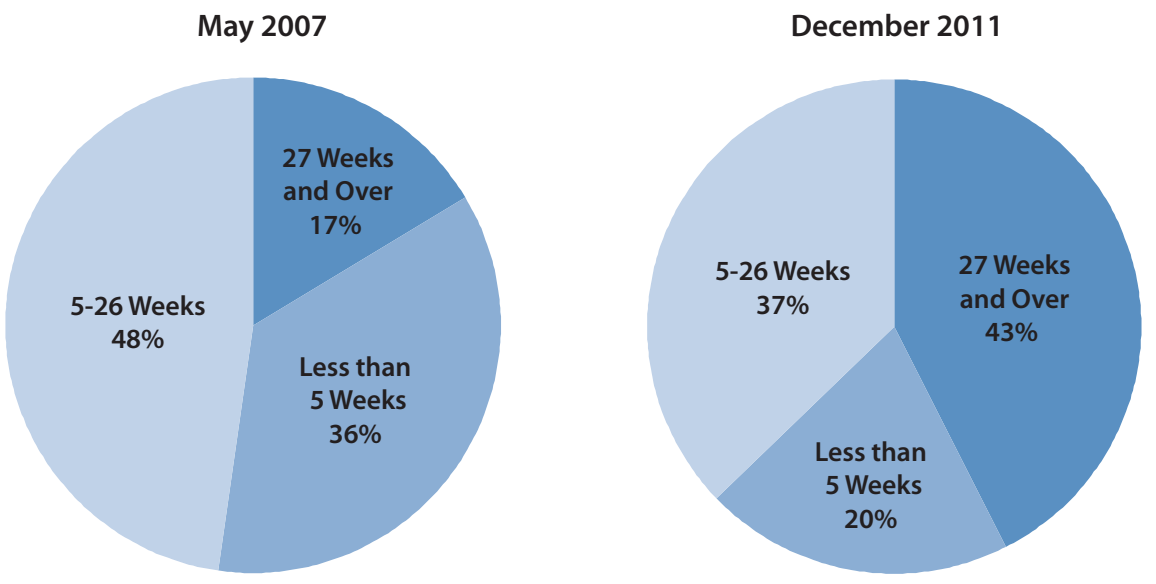

SOURCE: Bureau of Labor Statistics/Haver Analytics.

be due, in large part, to a "discouraged worker" effect, whereby unemployed workers facing bleak prospects stop looking for jobs. There also appears to be an "encouraged worker" effect; at least, this is one interpretation for the corresponding rise in the flow of nonparticipants choosing to enter the workforce.

Taken together, the data exhibited in Figure 6 reveal that the pattern of labor market activity over the course of booms and recessions is considerably more complicated than is generally recognized. As more and better data have become available, economists have been led to reassess existing labor market theories. In conventional theory, for example, unemployment is frequently portrayed as a stagnant pool of idle workers, waiting on the sidelines until market conditions improve.

In fact, the microdata show that for most workers, the length of their unemployment spells is relatively short; see the left-hand panel in Figure 7. This panel shows a fairly typical pattern: 84 percent of all unemployed workers in May 2007 had been unemployed for 26 weeks or less. However, while most unemployment spells are short, most of the time spent in unemployment is accounted for by a relatively small fraction of workers - the "long-term unemployed."

The right-hand panel in Figure 7 depicts the distribution of unemployment spells in December 2011. It still remains true that the majority of unemployment spells are of short duration, but the fraction is now much lower than it was prior to the recession. The fraction of unemployed workers who have been out of work longer than 26 weeks has risen to 43 percent. For policymakers, this post-recessionary increase in the fraction of long-term unemployment is disconcerting. If unemployment durations are short, at least the pain of unemployment is shortlived. But long-duration unemployment is more of a concern. This will certainly be the case if, as some fear, long unemployment spells lead to a deterioration of skills, rendering workers unemployable when the job market recovers. 


\section{Figure 8}

\section{U.S. Beveridge Curve, December 2000-November 2011}

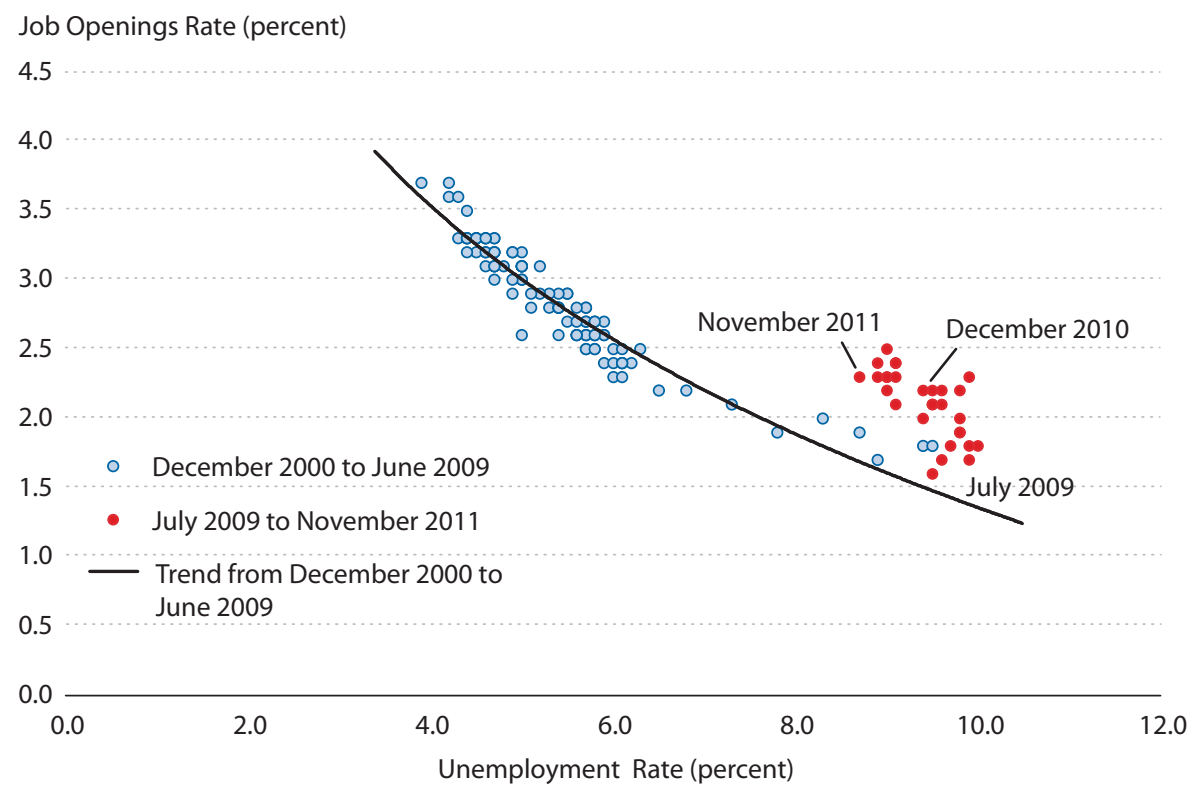

SOURCE: Job Openings and Labor Turnover Survey, Bureau of Labor Statistics/Haver Analytics.

\section{VACANCIES AND UNEMPLOYMENT}

A job vacancy corresponds to an "unemployed job" from the perspective of a firm. Unemployed workers are looking for unemployed jobs, and many unemployed jobs are looking for unemployed workers. $\stackrel{4}{ }$ On the surface, it seems puzzling that job vacancies should coexist with unemployment. Why do firms with job openings simply not hire available workers until the unemployment rate drops to zero or until the available supply of vacant jobs is exhausted?

One answer to this question is that resource allocation in the labor market is complicated by "search frictions." The basic idea is as follows: First, jobs and workers each possess idiosyncratic characteristics that make some job-worker pairings more productive than others. Second, jobs and workers do not necessarily know beforehand where the best pairing is located. If this is true, then it follows that jobs and workers should expend time and resources to search out the best matches. A firm will generally not want to hire the first worker who comes through the door. Likewise, an unemployed worker may not want to accept the first available job offer. The same principles are at work in most matching markets, including, for example, the marriage market.

Like unemployment, vacancies vary over the business cycle. In fact, unemployment and job vacancy rates tend to vary in a systematic way: The unemployment rate tends to be high when the vacancy rate is low and vice versa. The relationship between these two variables is referred to as the Beveridge curve. Figure 8 uses data from the Job Openings and Labor Turnover Survey to depict the Beveridge curve for the United States from December 2000 to November 2011. 


\section{Andolfatto and Williams}

From Figure 8, it seems that the Beveridge curve maintains its classic negative slope through most of the decade and, indeed, throughout the recent recession. The common interpretation of this pattern is that depressed business conditions lead firms to demand less labor and post fewer job openings, making it more difficult for unemployed workers to find jobs (that is, jobs well matched with their personal characteristics). Because jobs are harder to find, the unemployment rate rises.

The red dots in Figure 8 depict the Beveridge curve since the official end of the most recent U.S. recession-in June 2009. One would normally expect the unemployment rate to decline as economic growth resumes. But here we see evidence of increased recruiting activity on the part of the business sector together with a relatively small decline in the unemployment rate. One interpretation of this recent pattern is that matching jobs with workers has become more difficult in the wake of an exceptionally severe recession. If this is the case, then it is not immediately clear how monetary or fiscal policies might alleviate the problem.

\section{IMPLICATIONS FOR POLICY}

With the U.S. unemployment rate still very high, many are asking what might be done about it. It is not immediately clear what can be done in the short term. The Federal Reserve has lowered its policy rate as far as it can go. The economy is flush with liquidity. Many firms, however, remain reluctant to spend on investment and additional labor. For better or worse, political and fiscal constraints are holding back large expenditures on public works projects.

A key question, as far as policy is concerned, relates to why many firms appear reluctant to go "full speed ahead" in their investment and employment plans as the economy improves. This is where much of the disagreement lies. Some argue that private sector spending remains restrained by psychological factors-a simple lack of confidence. Others think that there are legitimate reasons for the apparent lack of confidence-including the policy uncertainty generated by the political machinations of the public sector. Where one falls between these two perspectives naturally influences one's view on what constitutes desirable policy.

On a brighter note, the U.S. economy is clearly in recovery mode, even if the recovery is not very robust. Real per capita GDP is growing, even if employment per capita is doing so at a slower pace. A growing GDP combined with low employment growth necessarily means higher labor productivity (more output is being produced with roughly the same amount of labor). Some people argue that higher productivity is responsible for the lack of hiring. But productivity has been rising for centuries, and with no obvious detriment to employment opportunities. The recovery in GDP, however, has done little to diminish the belief among some that "more should be done" to help the labor market. It is easy to understand what motivates this sentiment. GDP is a measure of average income-it sheds no light on how this income is distributed across the population. Moreover, the incidence of unemployment is concentrated among the poor and less educated. In short, there is a concern that the prosperity associated with the recovery will not be shared by all. Determining the best way to ensure shared prosperity without crippling the machine that creates it is always a challenge for policymakers-and it is likely to remain so in the foreseeable future. 
Andolfatto and Williams

\section{NOTES}

1 The measure of population referred to here includes those 16 years of age or older in the civilian, noninstitutional portion.

$\underline{2}$ The only exception to this rule is for those on temporary layoff. Only a small fraction of the unemployed falls into this category.

$\underline{3}$ If respondents say they have only "looked at want ads," they are also classified as nonparticipants.

4 Of course, many job openings are also targeted at employed workers; likewise, many employed workers are also looking for better jobs. The flow of employment to employment transitions is also very large.

\section{REFERENCES}

Davis, Steven J.; Faberman, R. Jason and Haltiwanger, John. "The Flow Approach to Labor Markets: New Data Sources and Micro-Macro Links," Journal of Economic Perspectives, Summer 2006, 20(3), pp. 3-26. 


\section{APPENDIX}

\section{A Closer Look at G-7 Labor Patterns during the 2007-09 Recession and Beyond}

In the two decades prior to the 2007-09 recession, the United States had one of the lowest unemployment rates among the world's major industrialized countries. As of the first quarter of 2007, for example, the U.S. unemployment rate stood at 4.5 percent, roughly half that of France and Germany. Only Japan's unemployment rate was lower among the Group of 7 (G-7) countries. ${ }^{1}$ See Figure A1.

During the Great Recession, the United States went from having one of the lowest unemployment rates to one of the highest. Two quarters after the recession ended, the U.S. unemployment rate peaked at 10 percent, roughly on par with France-a country whose unemployment rate stood at almost 9 percent just prior to the recession! Even more shocking to seasoned observers of world labor markets, the unemployment rate in Germany actually declined through much of the recession.

Why has the unemployment response to the recession been so different among G-7 countries? One explanation may simply be that the strength of recessionary forces varied across each country. If true, then one might expect a strong relationship between the change in the unemployment rate and the change in GDP across countries. If a country experienced only a small decline in GDP, then one would expect the change in unemployment to be correspondingly small in that country, and vice versa. In fact, this appears not to be the case at all.

Consider Figure A2, which plots the decline in GDP from peak to trough against the increase in the unemployment rate for each G-7 country. There appears to be little, if any, correlation between changes in GDP and unemployment. Compared with other G-7 countries, the United States experienced a relatively small decline in GDP during this recession-the third smallest decline in GDP after France and Canada. Of all G-7 countries, however, the United States experienced the largest increase in its unemployment rate.

\section{Figure A1}

\section{Unemployment Rate in G-7 Countries, 2007:Q1-2011:Q3}

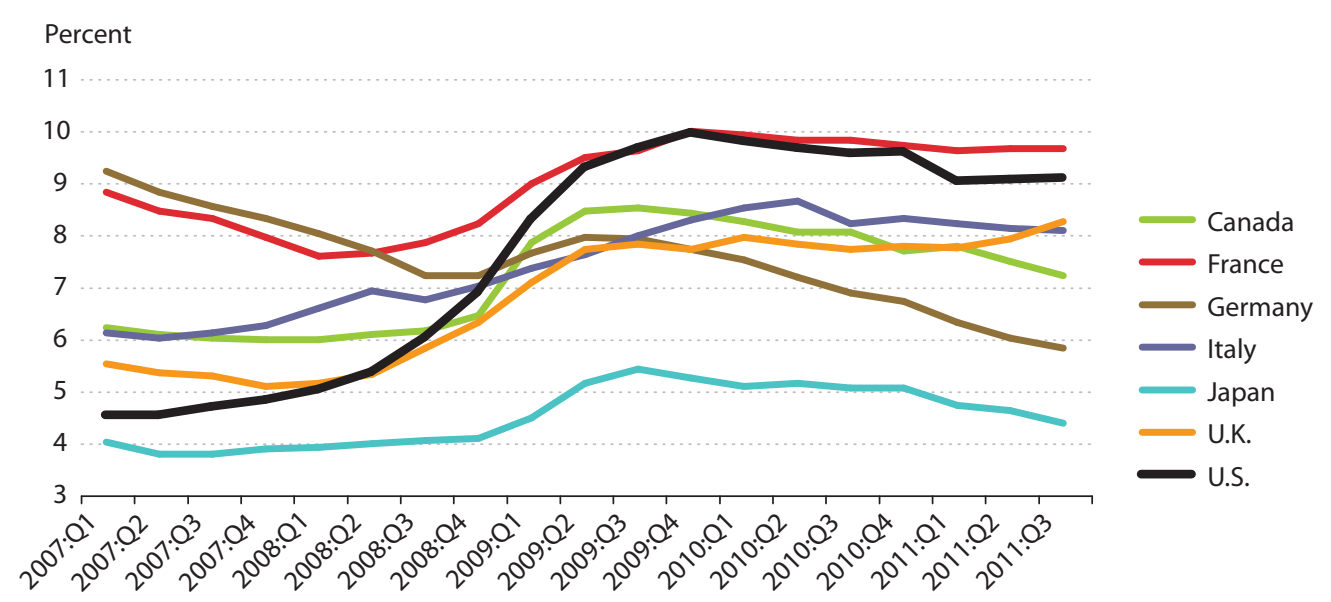




\section{Figure A2}

\section{The 2007-09 Recession: Impact on Real GDP and Unemployment in G-7 Countries}

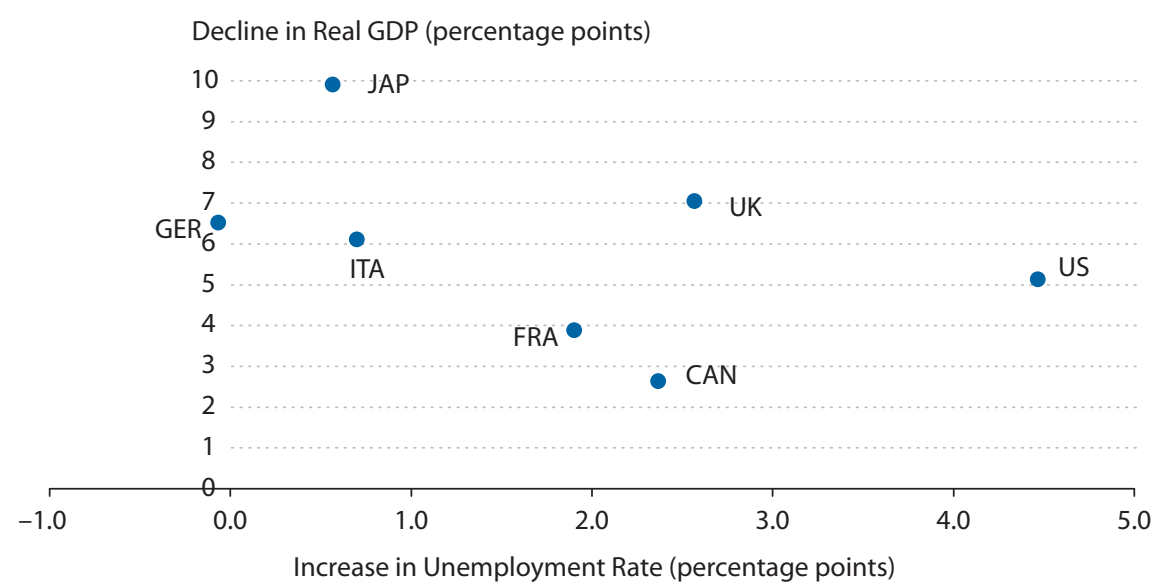

SOURCE: Data come from OECD/Haver Analytics. Peak and trough dates for each country are from the National Bureau of Economic Research (for the U.S.) or from the OECD (for the remaining G-7 countries).

\section{Figure A3}

\section{Civilian Employment in G-7 Countries, 2007:Q1-2011:Q4}

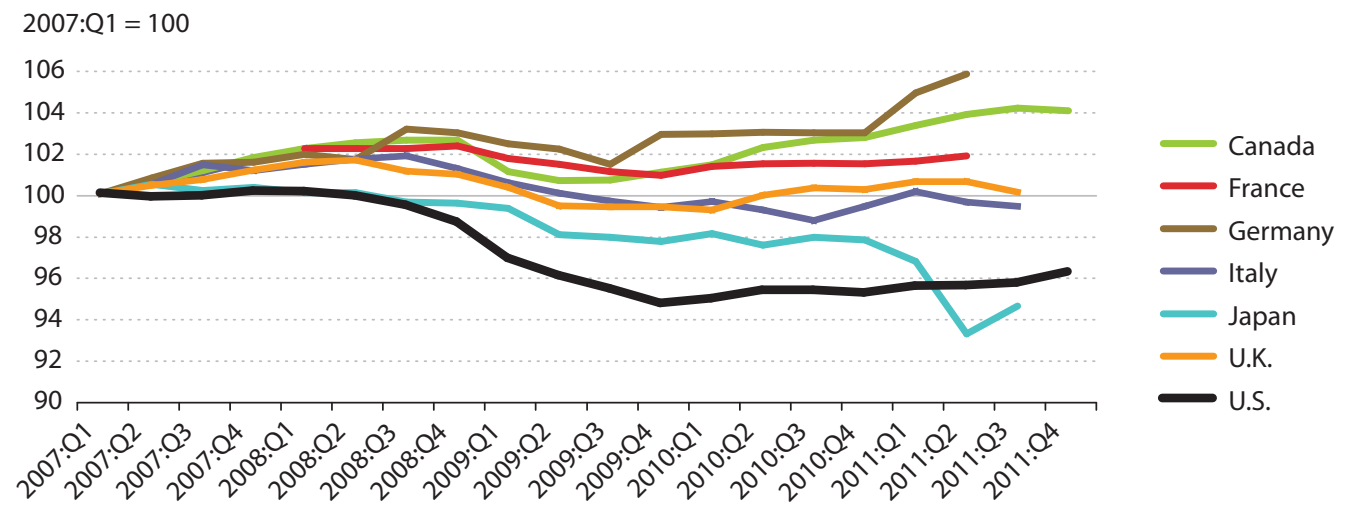

SOURCE: Statistics Canada, OECD, Bureau of Labor Statistics/Haver Analytics.

The level of employment in five of the seven G-7 countries over the course of the recession followed a broadly similar pattern. Figure A3 shows quarterly civilian employment for G-7 countries, with the series normalized to 100 in the first quarter of 2007. As the picture shows, the United States appears to be the most pronounced outlier here, shedding a significantly larger percentage of employees than the rest of the G-7 countries during the recession. Canada, Germany, and France actually saw their employment levels rise during the recession compared with the first quarter of 2007. The case of Japan is particular since it underwent natural disasters in March 2011, resulting in a roughly 6 percent decrease of its employment level compared with the first quarter of 2007. 


\section{Figure A4}

\section{Labor Productivity (GDP per Worker) for G-7 Countries, 2007:Q1-2011:Q3}

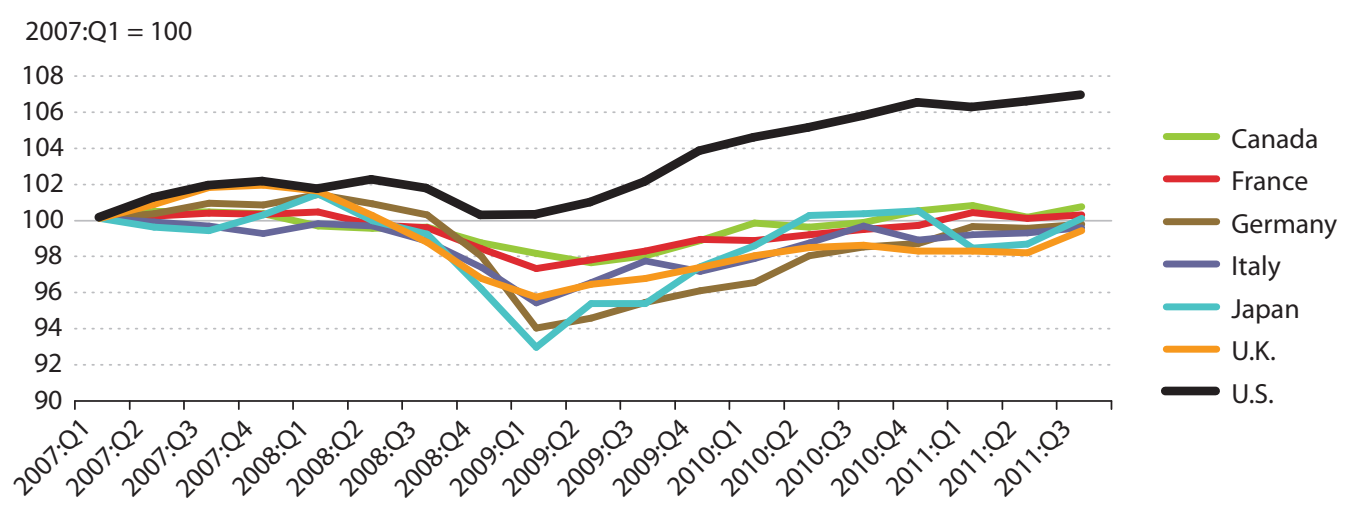

SOURCE: G10+ Database/Haver Select.

\section{Figure A5}

\section{Overall Strictness of Employment Protection OECD Index, 2008}

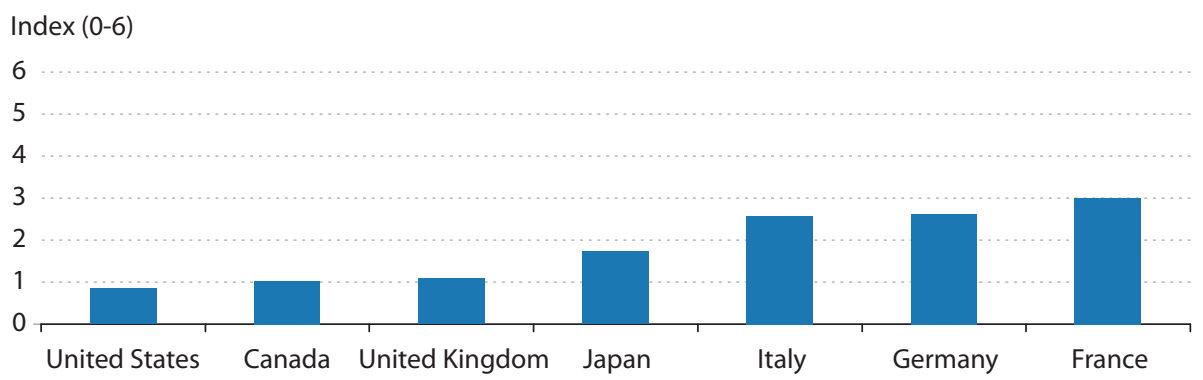

NOTE: The index ranges from 0 to 6 , with 0 representing the least-strict and 6 representing the most-strict employment protection. SOURCE: OECD Indicators of Employment Protection.

Employment normally contracts during a recession. Moreover, real GDP usually declines proportionately more than employment. The implication is that labor productivity-measured as output per workertends to decline during a recession. This commonly observed behavior was evident among all the G-7 economies during the past recession, with the notable exception of the United States; see Figure A4.

Figure A4 plots labor productivity (GDP per employed worker), normalized to 100 in the first quarter of 2007. As the figure illustrates, U.S. labor productivity remained higher than its 2007:Q1 level for the majority of the recession and has risen rapidly. Countries for which the impact of the recession on the unemployment rate was relatively small, such as Germany and Japan, saw output per worker decline significantly. As of the third quarter of 2011, only Canada, Japan, and France have exceeded pre-recession productivity levels at any point since the recession ended. 
As usual, there are several ways to interpret the data. First, it may be possible that the productivity of labor rose in the United States and that this event allowed U.S. firms to economize on labor. It is hard, however, to imagine a recession being the consequence of some random force that increased economy-wide labor productivity.

An alternative explanation is that low-skilled workers are affected disproportionately during a typical recession: They are the first ones to be let go. If this is the case, then the average quality of employed workers tends to rise during a recession. Perhaps this accounts for the increase in measured average labor productivity in the United States. If this hypothesis is correct, then to explain the data, one must be willing to entertain the idea that business managers are somehow more willing or able to lay off lower-skilled workers (or workers in general) in the United States relative to other G-7 economies. ${ }^{2}$

In fact, there is some evidence to suggest that cross-country differences in regulatory environments permit varying degrees of labor market flexibility. Figure A5, for example, compares the strictness of employment protection for G-7 countries according to a measure constructed by the Organisation for Economic Co-operation and Development (OECD). The index is a weighted sum of a set of employment protection indicators that measure the rules and costs regarding the firing of workers (individuals and groups) and the use of temporary contracts. As can be seen in the figure, employment protection varies quite a bit among G-7 countries, with the United States having the least-strict employment protection. $\frac{3}{}$

For most of the past 30 years, the U.S. labor market has outperformed most others, especially in terms of low unemployment rates. This relative success has been attributed, at least in part, to the alleged flexibility in the U.S. labor market. In particular, high unemployment in European countries is frequently linked to laws that make it difficult to shed workers and/or hire temporary workers. Less flexibility means less profitability for firms and, hence, less incentive to hire workers.

It is perfectly natural, then, to expect employment and unemployment to react more violently to cyclical forces in a flexible labor market. And, indeed, this appears to have been the case during the recent recession.

\section{NOTES}

1 The G-7 countries are Canada, France, Germany, Italy, Japan, the United Kingdom, and the United States.

$\underline{2}$ For more information on cross-country productivity, see DiCecio (2005).

$\underline{3}$ For more details on the OECD indicators of employment protection and more information on this topic, see OECD (2004), OECD (2011), and Venn (2009).

\section{REFERENCES}

DiCecio, Riccardo. “Cross-Country Productivity Growth." Federal Reserve Bank of St. Louis International Economic Trends, November 2005; http://research.stlouisfed.org/publications/iet/20051101/cover.pdf.

Organisation for Economic Co-operation and Development. "Employment Protection: The Costs and Benefits of Greater Job Security." OECD Policy Brief, September 2004; www.oecd.org/dataoecd/6/32/33736760.pdf.

Organisation for Economic Co-operation and Development. OECD Employment Outlook 2009: Tackling the Jobs Crisis. Paris: OECD Publishing, 2009.

Organisation for Economic Co-operation and Development. OECD Employment Outlook 2010: Moving Beyond the Jobs Crisis. Paris: OECD Publishing, 2010.

Organisation for Economic Co-operation and Development. "OECD Indicators of Employment Protection." Accessed on March 9, 2011; www.oecd.org/employment/protection.

Venn, Danielle. "Legislation, Collective Bargaining and Enforcement: Updating the OECD Employment Protection Indicators." Working Paper No. 89, OECD Social, Employment and Migration, 2009; www.oecd.org/dataoecd/36/9/43116624.pdf. 


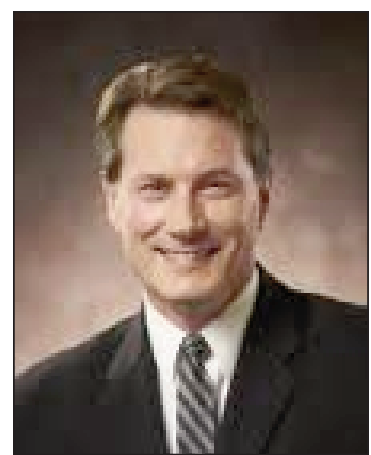

\section{Recent Research}

"Optimal Disclosure Policy and Undue Diligence," Federal Reserve Bank of St. Louis Working Paper 2012-001A, January 2012.

“Essential Interest-Bearing Money," Journal of Economic Theory, July 2010, 145(4), pp. 1319-602.

“Fiscal Multipliers in War and Peace," Federal Reserve Bank of St. Louis Review, March/April 2010, 92(2), pp. 121-27.

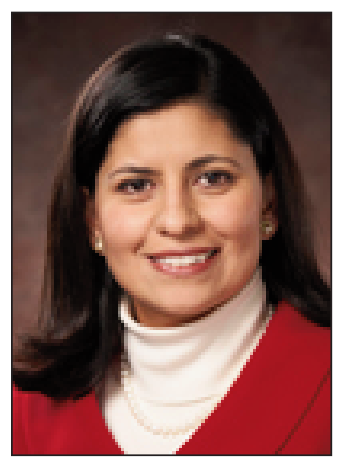

\section{Marcela M. Williams}

Public Affairs Officer, Federal Reserve Bank of St. Louis

\section{Research Focus}

Marcela Williams oversees the external communications function in the Bank's Public Affairs Department. Her research has analyzed currency and monetary policy issues.

\section{Recent Research}

"Currency Design in the United States and Abroad: Counterfeit Deterrence and Visual Accessibility," Federal Reserve Bank of St. Louis Review, September/October 2007, 89(5), pp. 371-414.

"U.S. Currency at Home and Abroad" Federal Reserve Bank of St. Louis Economic Synopses, 2007, No. 6.

"The Effectiveness of Monetary Policy," Federal Reserve Bank of St. Louis Review, September/October 2007, 89(5), pp. 447-89. 